\title{
Study of the effect of associative rhizobacterial strains on the formation of spring durum wheat productivity
}

\author{
Anna A. Belyaeva ${ }^{1, *}$, Oksana V. Tkachenko ${ }^{1}$, Gennady L. Burygin ${ }^{2}$, and Alma G. \\ Sundetova ${ }^{1}$ \\ ${ }^{1}$ Vavilov Saratov State Agrarian University, Department «Plant growing, breeding and genetics», \\ 410012 Saratov, Russia \\ ${ }^{2}$ Institute of Biochemistry and Physiology of Plants and Microorganisms Russian Academy of \\ Sciences, Laboratory of Immunochemistry, 410049 Saratov, Russia
}

\begin{abstract}
The article considers the influence of strains of associative rhizospheric growth-promoting bacteria on the growth and productivity of spring durum wheat. Seeds before sowing and plants in the tillering phase were inoculated with a suspension of rhizospheric bacteria Azospirillum brasilense of strains Sp245, Sp7, Cd, SR80 and SR88, Ochrobactrum cytisi IPA7.2, Enterobacter cloacae K7. Significant differences were observed in terms of productivity of inoculated wheat plants in comparison with the control. Two strains of bacteria $A$. brasilense SR80, SR88 promoted plant growth. Strains of rhizospheric bacteria $A$. brasilense Sp245, Sp7, SR80, SR88, and E. cloacae K7 under arid conditions of the Volga's Left Bank of the Saratov Region contributed to an increase in the photosynthetic surface of leaves and the productivity of photosynthesis, which affected the formation of spring durum wheat productivity. Strains of rhizospheric bacteria $A$. brasilense $\mathrm{Sp} 245$ and $\mathrm{Sp} 7$ positively affected the grain quality. Agrobiotechnology based on associative microsymbionts can be used to optimize environmentally sound technologies for the production of durum wheat (Triticum durum Desf.) in the organic farming system.
\end{abstract}

\section{Introduction}

Durum wheat (Triticum durum Desf.) is a traditional and one of the most important agricultural crops, which also has a large export potential. In recent years, areas of durum wheat cultivation in the Volga region have decreased due to the insufficient stability of the crop in terms of productivity and grain quality under increasing climate aridity [1-2]. Modern intensive technologies of crop growing and maintaining soil fertility require the application of a significant amount of chemical components, for example, mineral fertilizers, including nitrogen ones. Moreover, in arid conditions, the efficiency of applying mineral fertilizers not only drops sharply, but can have a negative effect on plants by increasing the total

\footnotetext{
* Corresponding author: belyaevaanna29@yandex.ru
} 
mineralization of the soil solution [1-4]. The use of "biological nitrogen", that is, fixation of atmospheric nitrogen by rhizospheric bacteria, is still not quite effective for cereals.

Environmentally sound technologies based on growth-promoting preparation can contribute to crop yield increasing. Morgun et al. [5] showed that growth-promoting preparations based on natural and synthetic organic components, applied in small quantities, actively affect the energy and plastic metabolism of plants. The application of preparations of this class leads to a reduction in interfacial periods, an increase in productivity, as well as to an anti-stress effect in relation to biotic and abiotic environmental factors. The advantage of biological products is low cost compared to others on the market $[2,5]$.

Significant interest of researchers around the world is attracted by preparations based on associative rhizospheric bacteria that can stimulate plant growth and productivity (Plantgrowth-promoting rhizobacteria (PGPR)). According to Tikhonovich et al. [10] and Zaworski et al. [4], PGPR-based preparations not only enrich plants and soil with nitrogen, but also have the ability to mobilize phosphorus and stimulate natural immunity to stress biota factors. In addition, rhizobacteria directly affect plant roots with biologically active substances, phytohormones, which leads to an increase in the energy of germinating ability of seeds and in yield. Reducing the cost of grain production allows one to significantly increase the profitability of production [5-8]. Kolesnikov et al. [9] showed a positive effect of rhizospheric microorganisms on agricultural plants, starting from the earliest stages of development, which consists in reducing their infection with phytopathogens and in yield increasing [5, 9-10]. The formation of phytohormones, vitamins, and other biologically active substances by bacteria is one of the most important mechanisms of interaction in plantbacterial associations $[5,9-12,15]$.

The mechanisms of mediated promotion of plant growth and non-specific immunity are based on the antagonistic relations of PGPR and phytopathogenic microorganisms: fungi and bacteria $[5,10,15]$. The antagonism of rhizobacteria against phytopathogens is realized in various ways, including by competing for such a vital nutrient as iron $[5,10]$. There are more than 500 siderophores, formed by soil microorganisms, including rhizobacteria.

The growth-promoting effect of rhizospheric bacteria is recorded under laboratory and field conditions. According to various researchers, when seeds are inoculated with rhizosphere strains of various taxonomic groups, an increase in germination, length and biomass of seedlings, an acceleration of plant growth rates, and an increase in photosynthesis productivity are noted $[13-14,16]$.

Growth-promoting activity and protective effect are some of the most important criteria for selecting promising bacterial strains to produce complex biological products based on them.

The purpose of this study was to study the effect of strains of associative rhizobacteria of various taxonomic groups during inoculation of seeds and plants on the formation of spring durum wheat productivity.

\section{Materials and methods}

The studies were conducted on the experimental field of the Saratov State Agrarian University, located in the Engels district of the Saratov region (the coordinates of the location of the site 51.114308, 46.024267). The conditions of the experiment are rainfed. The prevailing soil type is dark chestnut. In the year of the study, weather conditions were characterized as extremely arid. The object of research was a spring durum wheat cultivar Nikolasha. The seeds before sowing and plants in the tillering phase were inoculated with a suspension of the bacterial strains Azospirillum brasilense Sp245, Sp7, Cd, SR80 and SR88 
[17], Ochrobactrum cytisi IPA7.2 [18], as well as Enterobacter cloacae K7 [19], derived from pure bacterial cultures in the logarithmic growth phase. The cell concentration in suspension was $10^{8}$ in $1 \mathrm{ml}$. The control was an untreated variant, while the seeds before sowing and plants in the tillering phase were treated with water in the same amount as the variants treated with a suspension of bacteria.

Bacterial strains were taken from the collection of rhizospheric microorganisms of the Institute of Biochemistry and Plant Physiology and Microorganisms of the Russian Academy of Sciences No. 1021 (WDCM - WorldDataCentreforMicroorganisms) (http://collection.ibppm.ru).

The area of the experimental plots was $25 \mathrm{~m}^{2}$, three replications. Plant density, plant height, leaf area, total and productive bushiness were established by taking plant samples from sites of $0.25 \mathrm{~m}^{2}$, in three replications in each variant according to the main phases of plant development.

The counts and observations were carried out according to generally accepted methods. Phenological observations were carried out according to the methodology of the State cultivar testing of agricultural crops. Determination of plant standing density was carried out in the seedling phase and before harvesting on $0.25 \mathrm{~m}^{2}$ sites in three replications in each variant.

The assimilation apparatus of plants was determined by the leaf area calculated by the formula (1):

$$
S=k a d
$$

where $S$ is the area of the assimilation surface, $\mathrm{cm}^{2} ; k$ is the conversion factor $(0.7) ; a$ is the limb width, $\mathrm{cm} ; d$ is the limb length, $\mathrm{cm}$. When calculating the formation of the photosynthetic apparatus, it was recalculated per 1 hectare (thousand $\mathrm{m}^{2}$ ). The photosynthetic potential (FP) was determined as the product of the average assimilation apparatus by the time of its functioning (thousand $\mathrm{m}^{2} /$ ha day).

The net productivity of photosynthesis (NPF) was calculated by dividing the final value of the total biological yield by the photosynthetic potential during the growing season $\left(\mathrm{g} / \mathrm{cm}^{2}\right.$ day).

The analysis of productivity elements was carried out according to the methodology of the Research Institute of Agriculture of the South-East Region. The analysis took into account: the total mass of the test sheaf, the total and productive bushiness, the length of the ear, the amount of grain per ear, the weight of grain per ear, the weight of 1000 grains (three replications). Accounting for the actual grain yield was carried out according to all options at continuous allotment harvesting using the appropriate harvesting equipment. When calculating the yield, it was recount with standard grain moisture (14\%).

\section{Results and discussion}

The duration of the growing season phases in spring durum wheat cultivar Nikolasha did not differ significantly in variants.

In extreme dry year conditions, the variants with treatment with the bacterial strains $A$. brasilense Sp245, SR80, SR88 showed a promoting effect of plant growth in comparison with the control and other treatment options (Table 1).

The maximum height of spring durum wheat plants was in variants treated with strains of A. brasilense SR80, SR88 $(71 \mathrm{~cm})$. The indices in plants of these variants were significantly higher in comparison not only with the control, but also with other variants, which is 
confirmed by the result of analysis of variance (Table 1). This suggests that these plant strains increase the growth of vegetative mass under stressful conditions.

The maximum leaf area (19.7-19.8 thousand $\mathrm{m}^{2} / \mathrm{ha}$ ) was obtained in the variants treated with strains $A$. brasilense Sp245, SR88, E. cloacae K7. The leaf area in plants in the variants with inoculation with bacteria strains $A$.brasilense Sp245, SR88, E. cloacae K7 exceeded the control by $10-11 \%$. In the same variants, high photosynthetic potential was observed (Table 1).

Table 1. The formation of the assimilation apparatus and its productivity.

\begin{tabular}{|c|c|c|c|c|}
\hline Variant & $\begin{array}{c}\text { Plant height } \\
\text { before } \\
\text { harvesting, } \mathrm{cm}\end{array}$ & $\begin{array}{c}\text { Leaf area, } \\
\text { thousand } \\
\mathrm{m}^{2} / \mathrm{ha}\end{array}$ & $\begin{array}{c}\text { Photosynthetic } \\
\text { potential, thousand } \\
\mathbf{m}^{2} / \text { ha day) }\end{array}$ & $\begin{array}{c}\text { Net productivity } \\
\text { of } \\
\text { photosynthesis, } \\
\text { g/cm² day } \\
\end{array}$ \\
\hline Control & 62 & 17.8 & 1477.5 & 3.4 \\
\hline $\mathrm{Sp} 245$ & 69 & 19.8 & 1485.0 & 3.7 \\
\hline Sp7 & 67 & 18.2 & 1365.0 & 3.7 \\
\hline SR80 & 71 & 19.3 & 1222.0 & 3.8 \\
\hline SR88 & 71 & 19.7 & 1477.5 & 3.8 \\
\hline IPA7.2 & 65 & 18.9 & 1417.5 & 3.4 \\
\hline K7 & 68 & 19.8 & 1335.0 & 3.7 \\
\hline $\mathrm{Cd}$ & 62 & 18.1 & 1357.5 & 3.4 \\
\hline $\mathrm{LSD}_{0.05}$ & 2.43 & 0.509 & 10.944 & 0.328 \\
\hline
\end{tabular}

According to the authors, the dynamics of the formation of the assimilation apparatus was as follows: the maximum leaf area was formed in all studied variants during the flowering phase of wheat, and then a decrease in leaf area due to their dying was observed. The most contrasting options for the formation of leaf area are shown in Figure 1. Studies have shown that in variants with treatment with rhizospheric bacteria strains, the assimilation apparatus was $15-21 \%$ more viable compared to the control at the time of grain formation.

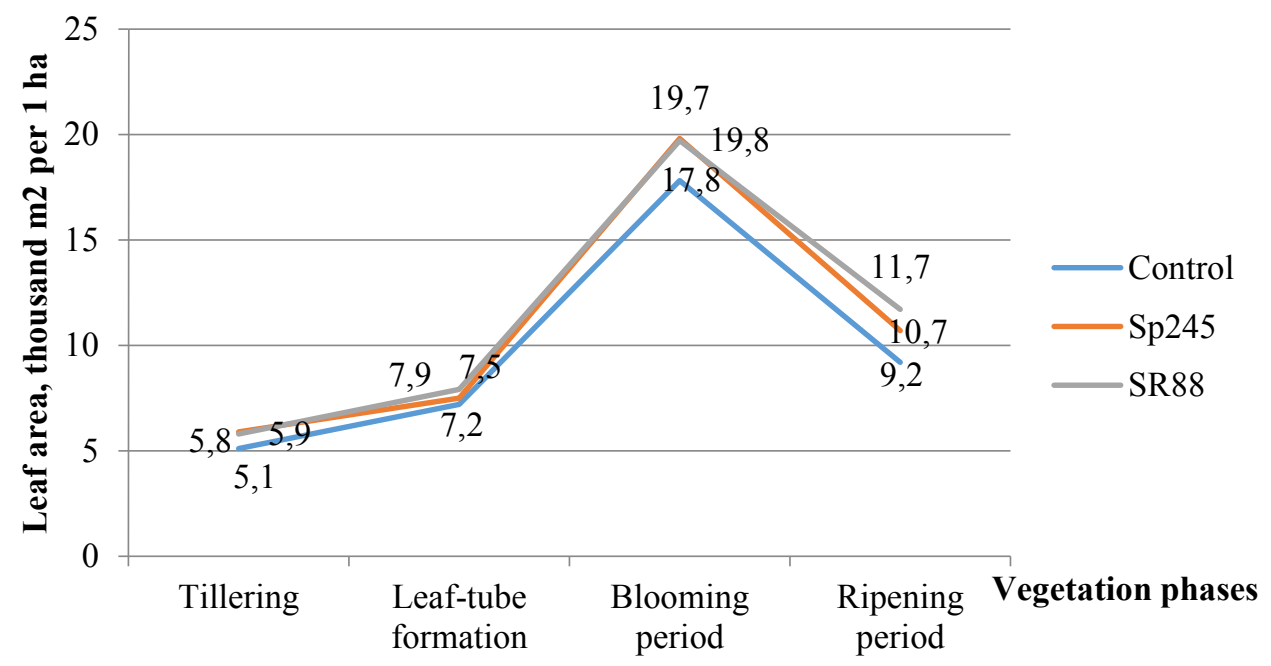

Fig. 1. Dynamics of leaf area formation in spring durum wheat (cultivar Nikolasha).

The maximum values of the net productivity of photosynthesis were in variants with strains of bacteria A. brasilense Sp245, Sp7, SR80, SR88, E. cloacae K7 (3.7-3.8 g/m² day). 
Plants in these variants significantly exceeded the control, as evidenced by analysis of variance.

According to the obtained data, a highly productive assimilation apparatus is formed in the variants with the bacterial strains A. brasilense Sp245, SR80, SR88, E. cloacae K7 (the leaf area was 19.3-19.8 thousand $\mathrm{m}^{2} / \mathrm{ha}$ ).

The yields of spring durum wheat varied from 1.21 to $1.34 \mathrm{t} / \mathrm{ha}$, which was caused by the conditions of low moisture supply to plants, especially in critical phases of development (tillering - flowering and grain formation). During the grain formation period, there was extremely low air humidity, so the grain was small and puny, which affected the yield of spring durum wheat (Table 2).

The yield in all studied variants of the experiment with inoculation with rhizospheric bacteria, with the exception of the $A$. brasilense Cd strain, significantly exceeded the control by $0.04-0.07 \mathrm{t} / \mathrm{ha}$. The maximum yield was in the variant with treatment with $A$. brasilense Sp7 strain (1.34 t/ha), although the vegetative mass in this variant was less than in other treated variants. This is due to the more efficient productivity of the assimilation apparatus $\left(3.7 \mathrm{~g} / \mathrm{m}^{2}\right.$ day) (Table 1$)$.

An analysis of the productivity elements of spring durum wheat confirms the positive effect of inoculation by bacteria on productivity. Productive bushiness in all variants was the same. The low supply of plants with moisture in the phase of lead-tube formation led to low indicators of productivity elements: productive bushiness and ear length; in the phase of flowering and grain formation - low indicators of the ear length, the number of grains per ear, the mass of 1000 grains. High rates of productivity elements were on the variant using A. brasilense Sp7 strain: grain weight per ear was 0.28 g, exceeding the control by $11 \%$, weight of 1000 grains - 33.4 g. Grain moisture in all variants varied from 9.9 up to $11.6 \%$.

Table 2. Yield and grain quality of spring durum wheat, $\mathrm{t} / \mathrm{ha}$.

\begin{tabular}{|c|c|c|c|}
\hline Variant & Grain yield, t/ha & Protein content, $\%$ & Gluten content, $\%$ \\
\hline Control & 1.27 & 17.6 & 29.8 \\
\hline Sp245 & 1.32 & 17.9 & 34.1 \\
\hline Sp7 & 1.34 & 18.1 & 32.5 \\
\hline SR80 & 1.31 & 17.6 & 33.6 \\
\hline SR88 & 1.32 & 17.3 & 30.8 \\
\hline IPA7.2 & 1.32 & 17.4 & 30.2 \\
\hline K7 & 1.31 & 17.6 & 30.6 \\
\hline Cd & 1.21 & 17.3 & 29.9 \\
\hline LSD 0.05 & 0.036 & 0.361 & 0.799 \\
\hline
\end{tabular}

This strain promoted the formation of productivity. The maximum content of protein and gluten (18.1 and 32.5\%, respectively) was also in the variant using A. brasilense Sp7 strain (Table 2).

The maximum protein content was in the variant using the bacterial strain $A$. brasilense Sp7 $-18.1 \%$, which is higher than the control by $2.8 \%$. High gluten content was in the variant using the bacterial strain A. brasilense Sp245 - 34.1\%, which is higher than the control by $12.7 \%$.

Due to the instability of meteorological conditions during the growing season, frequent droughts in the Left Bank of the Saratov Region, the use of modern techniques, such as treating seeds and plants with bacterial strains, are of particular importance. Inoculation of plants with rhizospheric nitrogen-fixing bacteria improves the processes of photosynthetic 
activity due to the absorption of soil nutrients from inaccessible forms. An important factor in the effect of bacteria on plants is their ability to increase the adaptability of plants to stressful conditions, including drought.

The ability of rhizospheric bacteria to promote the growth and productivity of durum wheat plants discovered in this study correlates with data from other authors. At the same time, the vast majority of studies were conducted on soft wheat. According to Brazilian scientists [8], the effect of the application of A. brasilense strains on spring wheat yield ranged from 15.4 to $25.4 \%$, depending on the conditions of the year. Similar results were obtained by Nunes et al. [11], according to which the wheat yield was $7.6 \%$ higher when $A$. brasilense was inoculated. The same results were obtained even in variants with high nitrogen availability, when sowing wheat after soybean with high capacity to accumulate nitrogen in the soil. In general, it can be noted that the application of nitrogen-fixing bacteria does not replace the application of fertilizers completely, but increases their efficiency, especially in adverse climatic conditions. For durum wheat with a productivity potential lower than that of spring soft wheat, the expected effect is likely to be slightly lower. But trends in the effect of bacterization persist.

The growth-promoting effect of bacteria is usually attributed to an increase in root system growth, which is caused by phytohormones produced by bacteria, with a focus on indoleacetic acid, gibberellins, and cytokinins [3, 12]. In addition, it is believed that the use of azospirill is also responsible for higher absorption of minerals and water [7] and high resistance to abiotic stresses such as salinization and drought [4]. According to Bashan and de-Bashan [3], in connection with a wide range of proposed mechanisms of influence, plant growth promotion by bacteria of the genus Azospirillum spp., is probably achieved by the combined action of several factors that can act either in a cumulative or sequential pattern.

\section{Conclusion}

Thus, the inoculation of seeds and plants of spring durum wheat (Triticum durum Desf.) cultivar Nikolasha under the extremely arid conditions of the Saratov Trans-Volga region with strains of associative rhizospheric bacteria A. brasilense Sp245, SR80, SR88, Ochrobactrum cytisi IPA7.2 and E. cloacae K7 contributed to the increase in plant productivity. Significant differences of inoculated wheat plants in comparison with the control were observed. Two strains of bacteria A. brasilense SR80, SR88 promoted plant growth. Strains of rhizospheric bacteria A. brasilense Sp245, SR80, SR88, and E. cloacae $\mathrm{K} 7$ contributed to an increase in the assimilation surface of plants and the productivity of the photosynthetic apparatus, which positively affected the formation of spring durum wheat productivity. The application of strains of rhizospheric bacteria A. brasilense Sp245 and Sp7 also had a positive effect on grain quality.

Agrobiotechnology based on the studied associative microsymbionts under conditions of increasing climate aridity can be used to optimize environmentally sound technologies for the production of durum wheat (Triticum durum Desf.) in the system of organic farming. Inoculation of seeds and plants with strains of associative rhizospheric bacteria allows forming a productive photosynthetic apparatus and stable yield of spring durum wheat.

\section{References}

1. A. A. Belimov, V. I. Safronova, Sovremennoe sostoyanie i perspektivy razvitiya mikrobiologii $i$ biotekhnologii [Proceedings of international scientific conference 
Current state and prospects of development of Microbiology and biotechnology] (Minsk, 2010)

2. M. V. Belyaeva, P. N. Mal'chikov, M. G. Myasnikova, E. N. Shabolkina, Immunitet, adaptivnost' $i$ kachestvo sortov yarovoj tvyordoj pshenicy $v$ srednem povolzh'e [Immunity, adaptivity and quality of spring durum wheat varieties in the middle Volga region] (Samara, 2018)

3. Y. Bashan, L. E. de-Bashan, Advances in Agronomy 108, 77 (2010). DOI: 10.1016/S0065-2113(10)08002-8

4. M. S. Zawonski, M. Ameneiros, M. P. Benavides, S. Vázquez, M. D. Groppa, Appl. Microbiol. Biotechnol. 90, 1389 (2011). DOI: 10.1007/s00253-011-3162-1

5. V. V. Morgun, S. Ya. Kots, E. V. Kirichenko, Fiziologiya i biohimiya kul'turnyh rastenij 41, 187 (2009)

6. A. A. Belimov, Vzaimodejstviya associativnyh bakterij s rasteniyami rol' abioticheskih $i$ bioticheskih faktorov [Interaction of associative bacteria with plants: the role of biotic and abiotic factors] (Palmarium, Germany, 2012)

7. M. S. Dardanelli, F. J. F. de Córdoba, M. R. Espuny, M. A. R. Carvajal, M. E. S. Díaz, A. M. G. Serrano, Y. Okon, M. Megías, Soil Biol. Biochem. 40, 2713 (2008). DOI: 10.1016/j.soilbio.2008.06.016

8. F. S. Galindo, M. C. M. T. Filho, S. Buzetti, W. L. Rodrigues, J. M. K. Santini, C. J. Alves, Acta Agriculturae Scandinavica 69, $606 \quad$ (2019). DOI: 10.1080/09064710.2019.1628293

9. L. E. Kolesnikov, A. A. Belimov, P. M. Dones, Izvestiya Saint-Petersburg State Agrarian University 1, 57 (2019)

10. I. A. Tikhonovich, L. V. Kravchenko, A. I. Shaposhnikov, Vestnik Rossijskoj Akademii Sel'skohozyajstvennyh Nauk 4, 19 (2010)

11. P. H. M. P. Nunes, L. A. Aquino, L. P. D. D. Santos, F. O. Xavier, L. R. Dezordi, N. S. Assunção, R Bras Ci Solo 39, 174 (2015)

12. B. Meza, L. E. de-Bashan, Y. Bashan, Research in Microbiology 166, 72 (2015)

13. G. A. Ignatova, Privolzhsky scientific Journal 6, 52 (2014)

14. V. S. Kursakova, T. G. Khizhnikova, L. A. Novikova, Vestnik Altajskogo Gosudarstvennogo Agrarnogo Universiteta 2, 23 (2014)

15. A. I. Shaposhnikov, A. A. Belimov, L. V. Kravchenko, D. M. Vivanko, Agricultural Biology 46, 16 (2011)

16. A. A. Belyaeva, O. V. Tkachenko, G. L. Burygin, A. G. Sundetova, Vavilovskie chteniya - 2019 [Proceedings of international scientific-practical conference Vavilovsky readings-2019], 15 (Amirit, Saratov, 2019)

17. K. Yu. Kargapolova, G. L. Burygin, O. V. Tkachenko, N. V. Evseeva, Ya. V. Pukhalskiy, A. A. Belimov, Plant Cell, Tissue and Organ Culture 141, 351 (2020). DOI: 10.1007/s11240-020-01791-9

18. G. L. Burygin, K. Yu. Kargapolova, Ye. V. Kryuchkova, E. S. Avdeeva, N. E. Gogoleva, T. S. Ponomaryova, O. V. Tkachenko, World J. Microbiol. Biotechnol. 35, 55 (2019). DOI: $10.1007 / \mathrm{s} 11274-019-2633-\mathrm{x}$

19. Ye. V. Kryuchkova, G. L. Burygin, N. E. Gogoleva, Yu. V. Gogolev, M. P. Chernyshova, O. E. Makarov, E. E. Fedorov, O. V. Turkovskaya, Microbiol. Res. 169, 99 (2014). DOI: 10.1016/j.micres.2013.03.002 